\title{
Newcastle Disease Virus Infection Promotes Bax Redistribution to Mitochondria and Cell Death in HeLa Cells
}

\author{
Aidin Molouki $^{\mathrm{a}}$ Yi-Te Hsu $^{\mathrm{c}}$ Fatemeh Jahanshiri ${ }^{\mathrm{a}}$ Rozita Rosli ${ }^{\mathrm{b}}$ Khatijah Yusoff ${ }^{\mathrm{a}}$ \\ a Department of Microbiology, Faculty of Biotechnology and Biomolecular Sciences, and \\ ${ }^{b}$ Department of Obstetrics and Gynaecology, Faculty of Medicine and Health Sciences, UPM, Serdang, Malaysia; \\ 'Department of Biochemistry and Molecular Biology, Medical University of South Carolina, Charleston, S.C., USA
}

\section{Key Words}

Newcastle disease virus · AF2240 • Apoptosis • Bax • Bcl-2 • HeLa

\begin{abstract}
Background/Aims: Newcastle disease virus (NDV) is an avian paramyxovirus that has gained a lot of interest in cancer viro-therapeutic applications because of its ability to selectively induce apoptosis in human cancer cells. However, the underlying mechanisms by which NDV induces apoptosis in human cancer cells are still not entirely understood. Methods: In this study we examined the effect of a Malaysian velogenic strain of NDV, known as AF2240, on some elements of the intrinsic pathway of apoptosis. Results: We show that NDV infection leads to conformational change of Bax protein. This is associated with the translocation of Bax from the cytoplasm to mitochondria and the release of cytochrome $c$ into the cytoplasm. Interestingly, the level of $\mathrm{BCl}-2$ protein was not affected by NDV treatment. Conclusion: We have shown that Bax conformational change and subcellular distribution is involved in the intrinsic pathway of apoptosis induced by NDV.

Copyright $\odot 2009$ S. Karger AG, Basel
\end{abstract}

\section{Introduction}

Newcastle disease virus (NDV) belongs to the genus Avulavirus from the family of Paramyxoviridae [1] which causes fatality in most species of birds, resulting in great economic impact on the poultry industry [2]. NDV has a non-segmented single-stranded negative-sense RNA genome of nearly $15 \mathrm{~kb}$ [3-5]. Upon endocytosis into the host cell, NDV genome is subjected to two separate mechanisms of transcription and replication; transcription into mRNAs to produce viral proteins $[6,7]$ and synthesis of a full-length positive-sense RNA which acts as a template for replication of more negative-sense RNAs [8]. Together, these two mechanisms function as a machinery to produce more viruses. Many strains of NDV have been isolated but this virus is mainly categorized by its pathotype and clinical effects rather than its RNA structure. Basically, lentogenic NDV strains cause clinically mild respiratory disease, mesogenic strains result in some respiratory and neurological symptoms with moderate mortality, and velogenic strains cause severe intestinal lesions and neurological effects with high mortality rates [9]. Strain AF2240 which is mostly used as the challenge virus in vaccine trials in Malaysia, is a viscerotropic velogenic strain of NDV that was isolated during an outbreak in the country in the 1960s [10]. This virus has a different hemagglutinin-neuraminidase protein compared to other strains [11].

\section{KARGER}

Fax +4161306 1234 E-Mail karger@karger.ch www.karger.com
Khatijah Yusoff, PhD, Department of Microbiology

Faculty of Biotechnology and Biomolecular Sciences, Universiti Putra Malaysia

43400 UPM, Serdang, Selangor DE (Malaysia)

E-Mail kyusoff@biotech.upm.edu.my 
Although NDV is not a human pathogen, its effect on human cancers has been widely reported [12-18]. In general, NDV appears to selectively kill cancer cells while sparing normal human cells [19]. It is believed that NDV kills avian cells and human cancer cells by apoptosis [20, 21].

Apoptosis is a form of cell death which is initiated via either intrinsic or extrinsic pathway [22]. Mitochondria are involved in both apoptotic signaling pathways [23]. The Bcl-2 family of proteins plays an important role in regulation of mitochondrial checkpoints. These proteins display both pro- and anti-apoptotic functions [24, 25]. $\mathrm{Bcl}-2$ displays primarily anti-apoptotic characteristics $[22,26]$ and it is a membrane protein that has been localized to nuclear outer membrane, endoplasmic reticulum and mitochondrial outer membrane $[24,27,28]$. Bax, on the other hand, is a pro-apoptotic member of this family [24]. It resides mainly in the cytoplasm of healthy living cells and it translocates to mitochondria upon the induction of apoptosis [29-31]. The conformational change of Bax, followed by the exposure of both of NH2- and $\mathrm{COOH}$-terminal segments, leads to its translocation to mitochondria [32]. It has been proposed that Bax forms oligomers on mitochondrial surface and Bcl-2 could block this oligomerization process [33]. Thus, it has been proposed that the ratio of $\mathrm{Bax} / \mathrm{Bcl}-2$ serves as a rheostat that regulates cellular survival vs. death [24, 34].

Previous observations show that, during NDV-induced apoptosis, both extrinsic and intrinsic pathways are activated and that the mitochondria membrane potential drops [35]. Furthermore, another study suggests that this event is independent of the role of p53 [36]. These observations prompted us to investigate the role of mitochondria and Bcl-2 family of proteins in NDV-induced apoptosis. We mainly focused on the Bax protein to see if infection with the AF2240 strain of NDV leads to its conformational change and subcellular distribution. We also investigated the level of $\mathrm{Bcl}-2$ protein to see if there is a disturbance in $\mathrm{Bax} / \mathrm{Bcl}-2$ rheostat and mitochondrial dysfunction as in the release of cytochrome $\mathrm{c}$ following NDV infection.

\section{Materials and Methods}

Virus and Cells

The Malaysian velogenic NDV strain AF2240 was grown in 9day-old embryonated chicken eggs and purified as previously described [37]. The virus titer was measured by hemagglutination activity (HA) assay. Human cervical cancer cell line, HeLa, was purchased from American Type Culture Collection and cultured in Dulbecco's modified Eagle's medium supplemented with $10 \%$ fetal bovine serum, $100 \mathrm{U}$ of penicillin/ml and $100 \mu \mathrm{g}$ of strepto$\mathrm{mycin} / \mathrm{ml}$ in $5 \% \mathrm{CO}_{2}$ at $37^{\circ}$. The infection of cells was performed according to a standard protocol with $30 \mathrm{HA}$ units of NDV per $10^{6}$ cells [38]. All viral works were carried out inside a culture hood at the Department of Microbiology of Universiti Putra Malaysia.

Detection of Apoptosis by DNA Laddering and Acridine Orange/Propidium Iodide Staining of Apoptotic Nuclei

DNA fragmentation was assessed using the Suicide Track ${ }^{\mathrm{TM}}$ DNA Ladder Isolation Kit (Calbiochem, USA). Briefly, cells were cultured to $80 \%$ confluency, and were then infected with NDV virus and harvested at different time points. Cellular DNA was extracted using the rapid extraction protocol as specified by the manufacturer and then ran on a $2 \%$ agarose gel stained with ethidium bromide. Acridine orange/propidium iodide (AO/PI) staining was performed as previously described [39]. At different time points, infected cells were harvested, pelleted down, and resuspended in a solution of AO/PI ( $1 \mu \mathrm{g} / \mathrm{ml}$ of each stain). Stained cells were immediately visualized by fluorescence microscopy to observe apoptotic nuclei.

\section{Subcellular Fractionation}

Subcellular fractionation was performed as previously described [40], but with minor modifications. Infected cells were collected at different time points and resuspended in mitochondrial buffer (70 mM Tris- $\mathrm{HCl}, 0.25 \mathrm{M}$ sucrose and $1 \mathrm{~mm}$ EDTA, $\mathrm{pH} 7.4$ ). An equal volume of ice-cold digitonin lysis buffer (2 mg/ ml, $19.8 \mathrm{~mm}$ EDTA, $0.25 \mathrm{M}$ D-mannitol and $19.8 \mathrm{mM}$ MOPS, $\mathrm{pH}$ 7.4) was added for $90 \mathrm{~s}$. Samples were then centrifuged twice at $300 \mathrm{~g}$ for $5 \mathrm{~min}$ to pellet the nuclei. The supernatant was further centrifuged at $17,000 \mathrm{~g}$ for $20 \mathrm{~min}$ to separate mitochondria from the cytosol.

\section{Immunofluorescence and Confocal Microscopy}

$\mathrm{HeLa}$ cells were plated on poly-D-lysine-coated glass coverslips. The cells were infected $24 \mathrm{~h}$ later with the NDV strain AF2240. At different time points post-infection, cells were fixed with $3.7 \%$ ice-cold paraformaldehyde for $10 \mathrm{~min}$, washed twice with ice-cold PBS, and then permeabilized with $0.25 \%$ Triton X100 in PBS for another $10 \mathrm{~min}$. The cells were subsequently blocked with 3\% BSA in PBST for $30 \mathrm{~min}-1 \mathrm{~h}$ and then incubated with primary antibodies (anti-Bax clone $6 \mathrm{~A} 7$ and anti-Bcl-2 clone 100, Invitrogen, USA; anti-cytochrome c clone 7H8, Biovision, USA) in PBST and 1\% BSA for at least $4-12 \mathrm{~h}$ at $4^{\circ}$. After washing, the cells were incubated with Alexa Fluor 488-conjugated goat anti-mouse (Invitrogen, USA) or FITC-conjugated goat antimouse (Santa Cruz, USA) in 1\% BSA in PBST at room temperature for $1 \mathrm{~h}$ in dark. Coverslips were washed and finally were treated with ProLong ${ }^{\circledR}$ gold antifade reagent (Invitrogen, USA) and put on glass slides. Visualization was carried out using the Leica DM RA2 fluorescence microscope or Olympus FV1000 confocal microscope.

\section{Detection of Bax Conformational Change by}

\section{Immunoprecipitation}

HeLa cells $\left(1 \times 10^{7}\right)$ were infected with NDV and analyzed at different time points. Infected dead floating cells were collected separately from infected adherent cells. All adherent cells, both infected and uninfected, were harvested by scraping. The collect- 


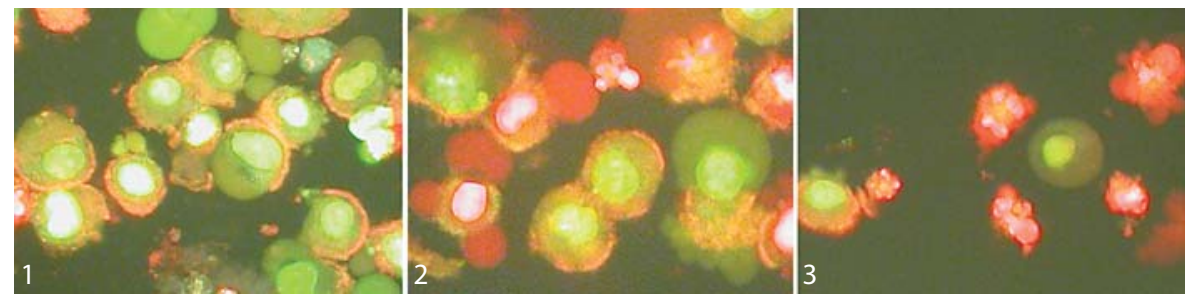

Fig. 1. Detection of apoptosis in NDV-infected HeLa cells. a Uninfected and NDV-infected HeLa cells were stained with AO/PI. Panels 1-3 are HeLa cells before infection, $6 \mathrm{~h}$ post-infection and $18 \mathrm{~h}$ post-infection respectively. Living cells were stained green while apoptotic cells were stained red (for colors see online version). b NDV infection induced DNA laddering in infected HeLa cells. Lane M: VC 100 bp plus DNA marker (Vivantis, Malaysia); lane 1: DNA extracted from HeLa cells 18 h post-infection; lane 2: DNA extracted from uninfected HeLa cells.

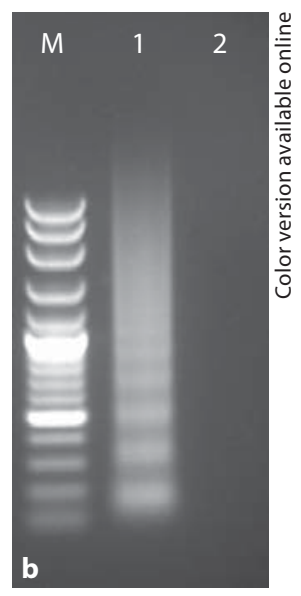

ed cells were washed twice in ice-cold PBS before being lysed in $200 \mu \mathrm{l} \mathrm{CHAPS} \mathrm{buffer} \mathrm{(1 \%} \mathrm{CHAPS,} 10 \mathrm{~mm}$ Hepes pH 7.4, $150 \mathrm{~mm}$ $\mathrm{NaCl}$, and protease inhibitor cocktail) $[41,42]$. The cell lysate was spun at $10,000 \mathrm{~g}$ (Sorvall, Legend Micro $17 \mathrm{R}$ ) for $15 \mathrm{~min}$ to pellet the nuclei and then incubated with antibody-coated protein $G$ beads overnight at $4^{\circ}$ on a rotator. The beads were then washed three times with the solubilization buffer containing 0.5\% CHAPS buffer. The beads were then mixed with 20-50 $\mu$ l SDS-PAGE sample loading buffer and boiled at $95^{\circ}$ for $10 \mathrm{~min}$. The supernatant was subjected to SDS-PAGE and Western blotting with rabbit polyclonal anti-Bax N20 antibody.

\section{SDS-PAGE and Western Blotting}

For Bax, Bcl-2, and $\beta$-actin studies, a $12.5 \%$ SDS-polyacrylamide gel and for cytochrome c studies, a 15\% gel was used. Gels were electrotransferred onto Immobilon-P membrane (Millipore Corp., USA) and after transferring, membranes were blocked with a casein buffer (Pierce, USA). The membranes were incubated with the primary antibodies at dilutions suggested by the manufacturers from $4 \mathrm{~h}$ to overnight at $4^{\circ}$. The blots were then incubated with secondary antibodies (AP-conjugated goat antimouse, Bethyl, USA; or AP-conjugated goat anti-rabbit, Abcam, USA) for $1 \mathrm{~h}$ at room temperature. NBT/BCIP alkaline phosphatase buffer (100 mM Tris-HCl pH 9.5, $100 \mathrm{mM} \mathrm{NaCl}, 10 \mathrm{mM} \mathrm{MgCl}_{2}$, containing $3 \mathrm{mg} / \mathrm{ml} \mathrm{NBT}$ and $1.5 \mathrm{mg} / \mathrm{ml} \mathrm{BCIP)}$ was used to develop the blotted membranes (Fermentas, USA). Membranes were also stripped and re-incubated with anti- $\beta$-actin antibody (Sigma, USA) to confirm equal protein loading. Furthermore, protein bands were scanned and a densitometric analysis was performed with Bio-Rad's Quantity One software version 4.2.2.

\section{Results}

\section{NDV Infection Leads to Cell Morphological Change and DNA Fragmentation}

HeLa cells were infected with NDV and at different time points, the cells were subjected to AO/PI labeling as described [39] (fig. 1a). Living cells only took up the acri- dine orange stain and could be seen as green under fluorescence microscope. Apoptotic cells which underwent morphological change and membrane blebbing were stained by propidium iodide and the condensed and fragmented nuclei could be seen as red. In our study, we found that morphological change of HeLa cells started to occur at $6 \mathrm{~h}$ post-infection.

In order to confirm the AO/PI staining of apoptotic HeLa cells, a DNA fragmentation assay was performed (fig. 1b). Total cellular DNAs from infected cells were isolated and then the fragmented DNA was separated from the heavy weight genomic DNA and analyzed by agarose gel electrophoresis. At $18 \mathrm{~h}$ post-infection, endonucleasemediated nucleosome excision was clearly observed as a DNA ladder (multimers of approximately $180-200$ base pairs) which is characteristic of apoptosis [43]. No fragmented DNA was observed before infection by NDV.

\section{NDV Infection Leads to the Release of Cytochrome c}

HeLa cells infected with NDV were subjected to immunofluorescence labeling with an anti-cytochrome $c$ $7 \mathrm{H} 8$ antibody at various time periods post-infection. The labeled cells were visualized by fluorescence microscope. As shown in figure $2 \mathrm{a}$, cytochrome $\mathrm{c}$ was localized primarily to mitochondria before infection. But $6 \mathrm{~h}$ post-infection, it became evident that in a number of cells, cytochrome $\mathrm{c}$ was released from mitochondria into the cytoplasm. A number of these cells were rounded up. At $16 \mathrm{~h}$ post-infection, more cells showed morphological changes and many started to detach and of the attached cells, more have shown a diffused cytoplasmic labeling of cytochrome c. At $32 \mathrm{~h}$ post-infection, almost all cells showed a diffused cytoplasmic cytochrome c labeling pattern. 


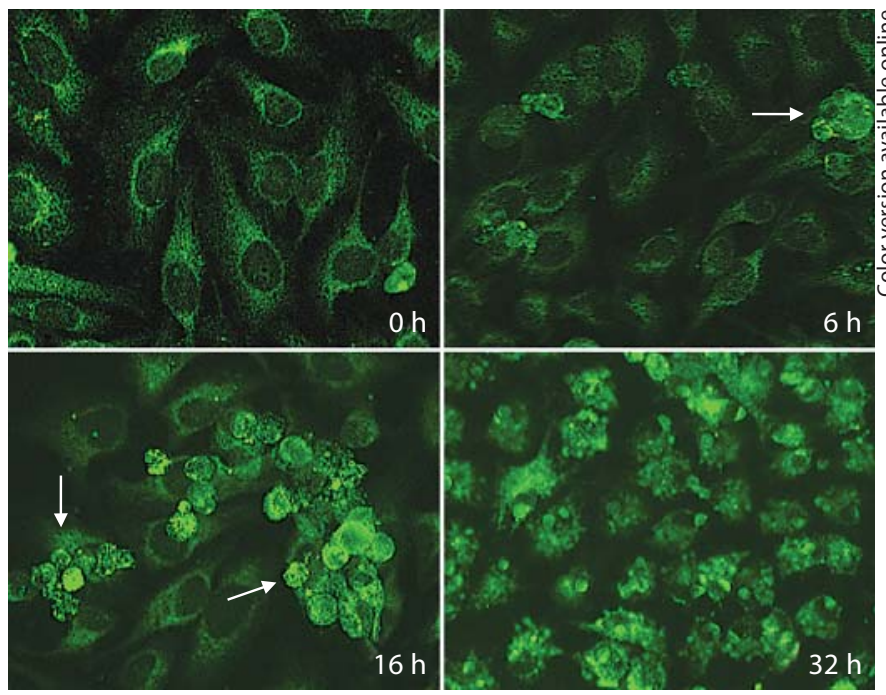

a

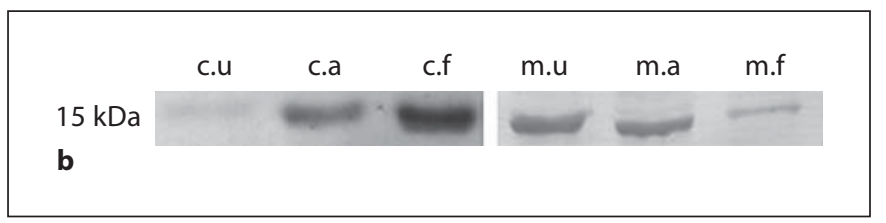

Fig. 2. NDV infection leads to the release of cytochrome $\mathrm{c}$ in $\mathrm{HeLa}$ cells. a Fluorescence images of HeLa cells labeled with an anticytochrome c 7H8 antibody at various times (0-32 h) after NDV infection. At $0 \mathrm{~h}$ post-infection, almost all cells had cytochrome $\mathrm{c}$ residing in mitochondria. At $6 \mathrm{~h}$ post-infection, a number of cells showed diffused labeling of cytochrome $\mathrm{c}$ and rounding up (white arrows). At $16 \mathrm{~h}$ post-infection, more cells showed morphological changes (white arrows) and many started to detach. At $32 \mathrm{~h}$ post-infection, almost all cells showed a cytoplasmic cytochrome c labeling pattern. b Detection of cytochrome c localization by subcellular fractionation. HeLa cells were subjected to NDV infection for $20 \mathrm{~h}$ and then subjected to subcellular fractionation. Infected adherent cells were collected separately from infected floating cells. The protein samples were analyzed by Western blotting analysis with an anti-cytochrome c 7H8 antibody ( $c$ = cytosolic fraction, $\mathrm{m}=$ heavy membrane fraction, $\mathrm{u}=$ uninfected cells, $\mathrm{a}=$ infected adherent cells, $\mathrm{f}=$ infected floating cells). Cytochrome c was primarily localized to mitochondria in uninfected cells. NDV infection leads to the release to cytochrome $\mathrm{c}$ in both infected adherent and floating cells.

To corroborate the immunofluorescence labeling results, subcellular fractionation was performed followed by Western blotting with an anti-cytochrome $\mathrm{c}$ antibody. HeLa cells were infected with NDV. Floating and adherent cells were collected separately at $20 \mathrm{~h}$ post-infection. As demonstrated in figure $2 \mathrm{~b}$, the cytosolic fraction of uninfected cells had little or no cytochrome c. On the other hand, in infected cells, especially the floating dead cells, a significant quantity of cytosolic cytochrome c was detected. Taken together, these results indicate the release of cytochrome $\mathrm{c}$ into the cytoplasm is an intrinsic event during the induction of apoptosis by NDV.

\section{Bax Conformational Change during NDV-Induced Apoptosis}

During apoptosis, a change in Bax conformation could be detected by a conformation-sensitive antibody $6 \mathrm{~A} 7$ $[29,32]$. In order to investigate the role of Bax in NDVinduced apoptosis, an immunoprecipitation analysis was carried out (fig. 3a). Cell lysates from uninfected and NDV-infected cells were subjected to immunoprecipitation with anti-Bax 6A7 antibody [42]. The immunoprecipitate samples were analyzed by Western blotting with an anti-Bax antibody. The results showed that little Bax binding to the $6 \mathrm{~A} 7$ antibody was observed in uninfected HeLa cells. However, at $18 \mathrm{~h}$ post-infection, especially in lysates from infected floating cells, a significant binding of Bax to the 6A7 antibody was observed. This suggests that Bax underwent a conformational change in HeLa cells during infection with the virus.

NDV-infected cells were also subjected to immunofluorescence labeling with the anti-Bax 6A7 antibody (fig. 3b). Very weak labeling was observed in untreated cells (fig. 3b; black arrow). However, as early as $6 \mathrm{~h}$ postinfection, 6A7 labeling became apparent in infected HeLa cells (fig. 3b; white arrow). This labeling appeared to occur prior to membrane blebbing. The intensity of labeling and the number of cells being labeled by this antibody were increased over time (fig. $3 \mathrm{~b}$; arrowheads). These results indicate that Bax undergoes a conformation change following apoptosis induction by NDV infection.

\section{Translocation of Bax from the Cytoplasm to \\ Mitochondria}

Subcellular fractionation was carried out to study the localization of Bax following NDV infection. The protein fractions were subjected to Western blotting analysis with the anti-Bax 2D2 antibody. As shown in figure 4, Bax was primarily localized to the cytosolic fraction before infection. However, after infection with NDV, the Bax level was decreased in the cytosolic fraction of infected adherent and this decrease was more evident in infected floating cells. In contrast, very little Bax was detected before infection in the heavy membrane fraction, which contains mitochondria. Bax level was increased in the heavy membrane fraction of infected cells, especially that obtained from the infected floating cells. 


\begin{tabular}{|c|c|c|c|c|}
\hline & $\mathrm{t}$ & $\mathrm{u}$ & a & $f$ \\
\hline $21 \mathrm{kDa}$ & & $6 x^{2}=$ & 6 & Henes \\
\hline a & & & & \\
\hline
\end{tabular}

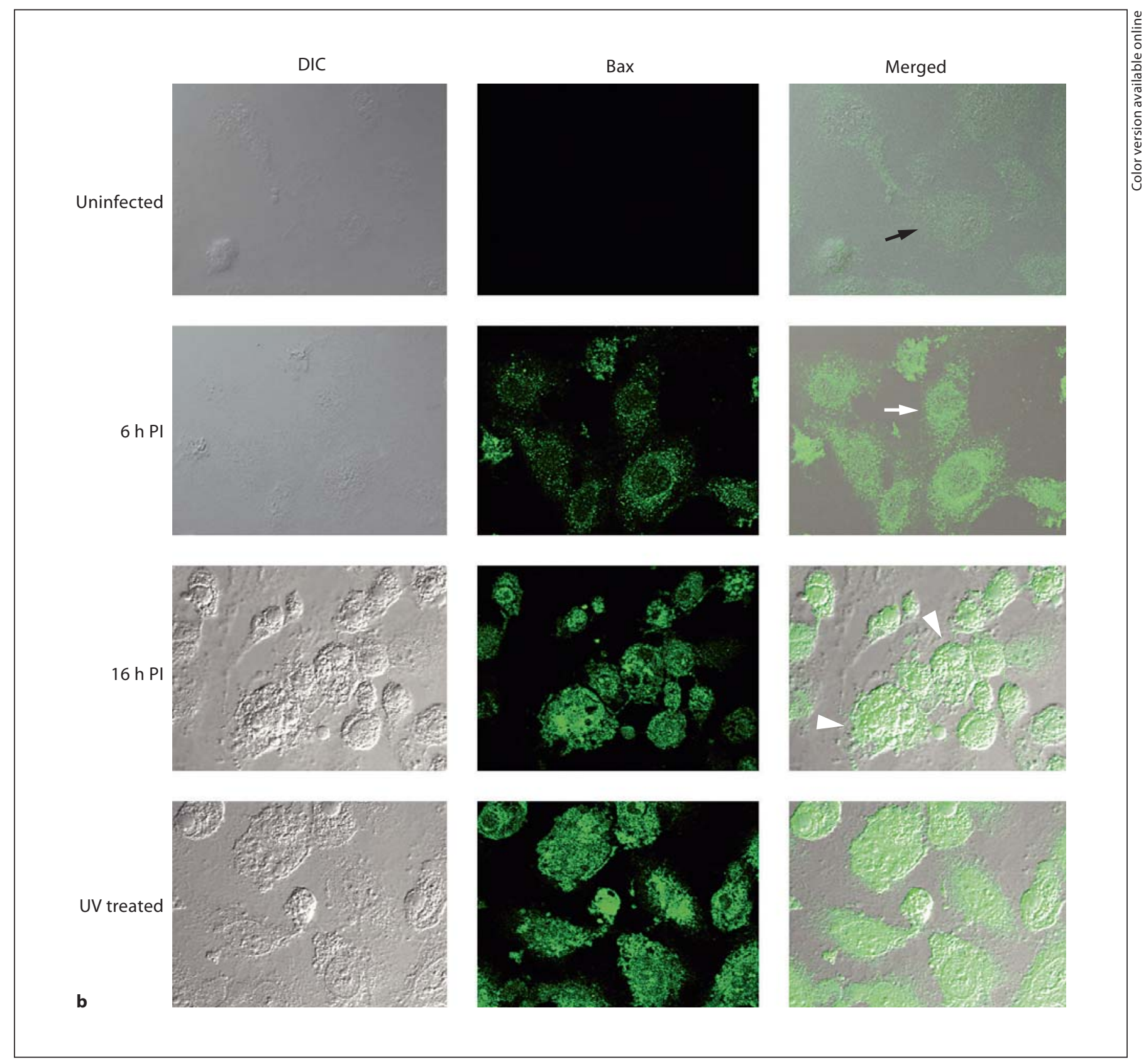

Fig. 3. Detection of Bax conformational change in HeLa cells infected with NDV. a Uninfected and NDV-infected HeLa cells were solubilized in Chaps and subjected to immunoprecipitation with the conformation-sensitive 6A7 antibody. The immunoprecipitated samples were subjected to Western blotting analysis with rabbit anti-Bax clone N20. $\mathrm{t}=$ Total HeLa lysate, $\mathrm{u}=\mathrm{IP}$ sample from uninfected cells, a = IP sample from infected adherent cells, $\mathrm{f}=\mathrm{IP}$ sample from infected floating cells. A significant change in
Bax conformation was detected in infected floating cells. b Confocal microscopy image of infected HeLa cells labeled with antiBax 6A7 antibody. Very week labeling was observed in uninfected cells (black arrow). At $6 \mathrm{~h}$ post-infection, 6A7 labeling became apparent (white arrow). At $16 \mathrm{~h}$ post-infection, a number of cells were labeled by the 6A7 antibody (arrowheads). UV-treated cells were used as control. NDV infection leads to activation and conformational change of Bax protein. 


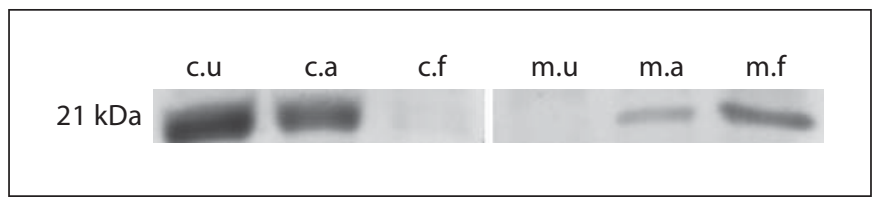

Fig. 4. Subcellular localization of Bax in NDV-infected HeLa cells. Uninfected and NDV-infected HeLa cells were subjected to subcellular fractionation. The protein samples were then analyzed by Western blotting analysis with the anti-Bax 2D2 antibody (c = cytosolic fraction, $\mathrm{m}=$ heavy membrane fraction, $\mathrm{u}=$ uninfected cells, $\mathrm{a}=$ infected adherent cells, $\mathrm{f}=$ infected floating cells). Bax was primarily localized to the cytosolic fraction before the infection but it translocated to the heavy membrane fraction after infection with the NDV strain AF2240, especially in infected floating cells.

\section{NDV Infection Did Not Alter Bax and Bcl-2 Protein} Expression Levels in HeLa Cells

An immunofluorescence labeling study was performed with the anti-Bcl-2 clone 100 antibody to assess whether Bcl-2 level was altered following NDV infection. We found that the intensity of Bcl-2 did not change between uninfected and infected cells (up to $18 \mathrm{~h}$ post-infection; data not shown). In addition, we have carried out a subcellular fractionation analysis of uninfected and infected cells. As shown in figure 5a, the heavy membrane fraction from uninfected and infected HeLa cells contained equivalent levels of $\mathrm{Bcl}-2$. No Bcl-2 was detected in the cytosolic fractions in agreement with previous studies.

Furthermore, cell lysates from uninfected and NDVinfected HeLa cells were subjected to Western blotting analyses with anti- $\beta$-actin, Bax $2 \mathrm{D} 2$, and Bcl-2 clone 100 antibodies. The labeled Bax and Bcl-2 bands were subjected to densitometric scans and normalized to $\beta$-actin. The results showed that following NDV infection, there was no significant change in the levels of Bax and Bcl-2 proteins, and that $\mathrm{Bax}$ to $\mathrm{Bcl}-2$ ratio remained relatively constant (fig. 5b).

\section{Discussion}

Apoptosis is a form of cell death that could be initiated via either intrinsic or extrinsic signaling pathways [22]. Several viruses have been shown to inhibit apoptosis by the strategies that they have evolved in order to secure their propagation in the infected cells [44]. On the other hand, many viruses are known to induce apoptosis in cells via the extrinsic, intrinsic, or both signaling pathways [44]. NDV is believed to promote cellular apoptosis via both pathways [35]. In this report, we show that NDV infection leads to apoptosis as determined by the release of cytochrome c, DNA laddering, and nuclear fragmentation; release of cytochrome c into cytoplasm was monitored during NDV-induced apoptosis in HeLa cells by immunofluorescence and subcellular fractionation experiments. In addition, we have shown that Bax redistribution from the cytoplasm to mitochondria is involved in the signaling mechanism leading to cell death. Moreover, we show that NDV infection did not alter the Bax/ $\mathrm{Bcl}-2$ ratio at the protein level.

During apoptosis, Bax protein N-terminal and C-terminal regions are exposed [29,32]. This is associated with Bax translocation from the cytoplasm to mitochondria [30-32]. Mitochondrial-bound Bax undergoes oligomerization on mitochondrial outer membranes, facilitating the release of apoptogenic factors such as cytochrome c $[45,46]$. In our study, by immunoprecipitation and immunofluorescence methods, we found that NDV infection leads to the exposure of the Bax N-terminal epitope, the redistribution of Bax to mitochondria, and the release of cytochrome c. It is conceivable that NDV infection initiates a signaling pathway leading to conformational change of Bax protein resulting in its redistribution to mitochondria. This mitochondrial bound Bax likely leads to mitochondrial permeabilization resulting in cytochrome $c$ release.

Bcl-2 has been shown to inhibit Bax oligomerization process [46]. It has been proposed that the ratio of Bax/ Bcl-2 serves as a rheostat that dictates cell survival vs. death $[24,34]$. By real-time PCR it has been recently reported that in NDV-infected Vero cells, Bax/Bcl-2 ratio is increased [47]. In our study, by Western blotting analysis of cell lysates, we did not detect significant changes in the total levels of these two proteins before and after infection with the NDV strain AF2240, indicating that the ratio of $\mathrm{Bax} / \mathrm{Bcl}-2$ at the protein level remained constant. This suggests that the endogenous Bcl-2 was not sufficient to inhibit the pro-apoptotic function of Bax in HeLa cells upon infection and also the alteration in Bax/ $\mathrm{Bcl}-2$ rheostat is not involved in NDV-mediated cell death.

Tumor suppressor $\mathrm{p} 53$ has been proposed as a regulator of Bax and $\mathrm{Bcl}-2$ proteins during apoptosis [48]. However, it has been previously shown that NDV kills cancer cells independently of p53 [36], suggesting that p53 is not in NDV-mediated Bax redistribution. On the other hand, $\mathrm{BH} 3$ domain-only proteins of the Bcl-2 family such as 


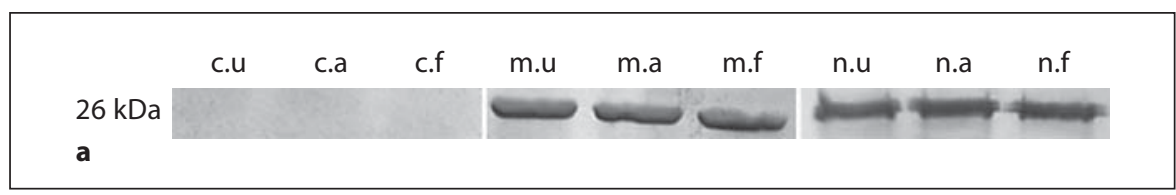

Fig. 5. No significant change in the protein levels of Bax and Bcl-2 after infection with NDV. a Subcellular localization of Bcl-2 in NDV-infected HeLa cells. Uninfected and NDV-infected HeLa cells were subjected to subcellular fractionation. Protein samples were then analyzed by Western blotting with anti-Bcl-2 100 antibody (c = cytosolic fraction, $\mathrm{m}=$ heavy membrane fraction, $\mathrm{n}=$ nuclear fraction, $\mathrm{u}=$ uninfected cells, $\mathrm{a}=\mathrm{in}$ fected adherent cells, $\mathrm{f}=$ infected floating cells). No significant change in the level of Bcl-2 was observed in HeLa cells' heavy membrane and nuclear fractions before and after infection with the NDV strain AF2240. b Cells were lysed and analyzed by Western blotting for levels of $\mathrm{Bax}, \mathrm{Bcl}-2$, and $\beta$-actin proteins. Bar graph represents a densitometric scan of the Western blots of the ratio of Bax/Bcl-2 as normalized to $\beta$-actin (mean \pm SEM, $\mathrm{n}=4)$.

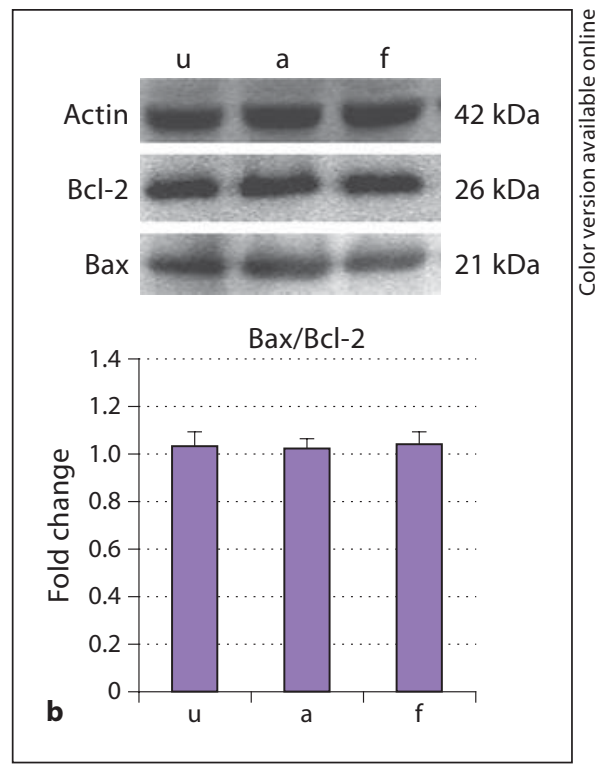

Bad, Bid and Bim are believed to activate and displace Bax [49-52]. It is possible that NDV infection activates these $\mathrm{BH} 3$-only proteins, leading to Bax conformational change and subcellular redistribution.

Recent studies show that viruses have mixed effects on Bax protein as some induce apoptosis by activation of Bax $[53,54]$ and some block apoptosis by inhibition of conformational activation of Bax $[55,56]$. Our study shows a conformational change and redistribution of Bax after
NDV infection. In the future, it would be interesting to determine the signaling mechanism by which NDV mediates this process.

\section{Acknowledgements}

A. Molouki was supported by a GRF scholarship, UPM. This research was supported by Malaysian Genome Institute Grant MGI-NBD0017-2007.

\section{References}

1 Mayo MA: A summary of the changes recently approved by ICTV. Arch Virol 2002; 147:1655-1656.

2 Alexander DJ: Newcastle disease and other avian Paramyxoviridae infections; in Caineck BW (ed): Diseases of Poultry. Ames, Iowa State University Press. 1997, pp 541569.

3 Krishnamurthy S, Samal SK: Nucleotide sequences of the trailer, nucleocapsid protein gene and intergenic regions of Newcastle disease virus strain Beaudette $\mathrm{C}$ and completion of the entire genome sequence. J Gen Virol 1998;79:2419-2424.

-4 Phillips RJ, Samson ACR, Emmerson PT: Nucleotide sequence of the 59-terminus of Newcastle disease virus and assembly of the complete genomic sequence: agreement with the 'rule of six'. Arch Virol 1998;143:19932002.
5 De Leeuw O, Peeters B: Complete nucleotide sequence of Newcastle disease virus: evidence for the existence of a new genus within the subfamily Paramyxovirinae. J Gen Virol 1999;80:131-136.

6 Hamaguchi M, Yoshida T, Nishikawa K, Naruse $\mathrm{H}$, Nagai Y: Transcriptive complex of Newcastle disease virus. I. Both $L$ and $P$ proteins are required to constitute an active complex. Virol 1983;128:105-117.

7 Hamaguchi M, Nishikawa K, Toyoda T, Yoshida T, Hanaichi T, Nagai Y: Transcriptive complex of Newcastle disease virus. II. Structural and functional assembly associated with the cytoskeletal framework. Virology 1985;147:295-308.

8 Lamb RA, Kolakofsky D: Paramyxoviridae: the viruses and their replication; in Fields BN, Knipe DM, Howley PM (eds): Fields Virology, ed 3. Philadelphia, Lippincott-Raven, 1996, pp 1177-1203.
9 Yusoff K, Tan WS: Newcastle disease virus: macromolecules and opportunities. Avian Pathol 2001;30:439-455.

10 Lai MC, Ibrahim AL: Velogenic viscerotropic Newcastle disease virus; in Copland JW (ed): Newcastle Disease in Poultry: a New Food Pellet Vaccine. ACIAR Monograph 5, Canberra, 1987, pp 33-34.

-11 Tan WS, Lau CH, Ng BK, Ibrahim AL, Yusoff $\mathrm{K}$ : Nucleotide sequence of the haemagglutinin-neuraminidase $(\mathrm{HN})$ gene of a Malaysian heat-resistant viscerotropic-velogenic Newcastle disease virus. DNA Seq 1995;6: 47-50.

12 Cassel WA, Garrett RE: Newcastle disease virus as an antineoplastic agent. Cancer 1965; $18: 863-868$

13 Csatary LK: Viruses in the treatment of cancer. Lancet 1971;ii:825. 
14 Lorence RM, Rood PA, Kelley KW: Newcastle disease virus as an antineoplastic agent: induction of tumor necrosis factor- $\alpha$ and augmentation of its cytotoxicity. J Natl Cancer Inst 1988;80:1305-1312.

-15 Schirrmacher V, Ahlert T, Probstle T, Steiner $\mathrm{HH}$, Herold-Mende C, Gerhards R, Hagmuller E, Steiner HH: Immunization with virus-modified tumor cells. Semin Oncol 1998;25:677-696.

- 16 Phuangsab A, Lorence RM, Reichard KW, Peeples ME, Walter RJ: Newcastle disease virus therapy of human tumor xenografts: antitumor effects of local or systemic administration. Cancer Lett 2001;172:27-36.

- 17 Pecora AL, Rizvi N, Cohen GI, Meropol NL, Sterman D, Marshall JL, Goldberg S, Gross P, O’Neil JD, Groene WS, Roberts MS, Rabin $\mathrm{H}$, Barmat MK, Lorence RM: Phase I trial of intravenous administration of PV701, an oncolytic virus, in patients with advanced solid cancers. J Clin Oncol 2002;20:2251-2266.

18 Zhao H, Janke M, Fournier P, Schirrmacher V: Recombinant Newcastle disease virus expressing human interleukin-2 serves as a potential candidate for tumor therapy. Virus Res 2008;136:75-80.

-19 Reichard KW, Lorence RM, Cascino CJ, Peeples ME, Walter RJ, Fernando MB, Reyes HM, Greager JA: Newcastle disease virus selectively kills human tumor cells. J Surg Res 1992;52:448-453.

-20 Lam KM, Vasconcelos AC, Bickford AA: Apoptosis as a cause of death in chicken embryos inoculated with Newcastle disease virus. Microb Pathog 1995;19:169-174.

-21 Washburn B, Weigand MA, Grosse-Wilde A, Janke M, Stahl M, Rieser E, Sprick MR, Schirrmacher V, Walczak H: TNF-related apoptosis-inducing ligand mediates tumoricidal activity of human monocytes stimulated by Newcastle disease virus. J Immunol 2003; 170:1814-1821.

22 Ekert PG, Vaux D: Apoptosis and the immune system. Br Med Bull 1997;53:591-603.

23 Wang X: The expanding role of mitochondria in apoptosis. Genes Dev 2001;15:29222933.

-24 Oltvai ZN, Milliman CL, Korsmeyer SJ: Bcl2 heterodimerizes in vivo with a conserved homolog, Bax, that accelerates programmed cell death. Cell 1993;74:609-619.

-25 Roulston A, Marcellus RC, Branton PE: Viruses and apoptosis. Annu Rev Microbiol 1999;53:577-628.

26 Yang E, Korsmeyer SJ: Molecular thanatopsis: a discourse on the Bcl-2 family and cell death. Blood 1996;88:386-401.

-27 Jacobson MD, Burne JF, King MP, Miyashita T, Reed JC, Raff MC: Bcl- 2 blocks apoptosis in cells lacking mitochondrial DNA. Nature 1993;361:365-369.

-28 Krajewski S, Tanaka S, Takayama S, Schibler MJ, Fenton W, Reed JC: Investigation of the subcellular distribution of the Bcl-2 onco- protein: residence in the nuclear envelope, endoplasmic reticulum, and outer mitochondrial membranes. Cancer Res 1993;53: 4701-4714.

29 Hsu YT, Wolter KG, Youle RJ: Cytosol-tomembrane redistribution of $\mathrm{Bax}$ and $\mathrm{Bcl}-\mathrm{X}_{\mathrm{L}}$ during apoptosis. Proc Natl Acad Sci USA 1997;94:3668-3672.

30 Wolter KG, Hsu YT, Smith CL, Nechushtan A, Xi XG, Youle RJ: Movement of Bax from the cytosol to mitochondria during apoptosis. J Cell Biol 1997;139:1281-1292.

31 Gross A, Jockel J, Wei MC, Korsmeyer SJ: Enforced dimerization of Bax results in its translocation, mitochondrial dysfunction and apoptosis. EMBO J 1998;17:3878-3885.

32 Nechushtan A, Smith CL, Hsu YT, Youle RJ: Conformation of the Bax C-terminus regulates subcellular location and cell death. EMBO J 1999;18:2330-2341.

33 Dlugosz PJ, Billen LP, Annis MG, Zhu W, Zhang Z, Lin J, Leber B, Andrews DW: Bcl-2 changes conformation to inhibit Bax oligomerization. EMBO J 2006:25:2287-2296.

34 Sedlak TW, Oltvai ZN, Yang E, Wang K, Boise LH, Thompson CB, Korsmeyer SJ: Multiple Bcl-2 family members demonstrate selective dimerization with Bax. Proc Natl Acad Sci USA 1995;92:7834-7838.

- 35 Elankumaran S, Rockermann D, Samal SK: Newcastle disease virus exerts oncolysis by both intrinsic and extrinsic caspase-dependent pathways of cell death. J Virol 2006;80: 7522-7534.

-36 Fabian Z, Csatary CM, Szeberenyi J, Csatary LK: p53-independent endoplasmic reticulum stress-mediated cytotoxicity of a Newcastle disease virus strain in tumor cell lines. J Virol 2007;81:2817-2830.

-37 Ramanujam P, Tan WS, Nathan S, Yusoff K Novel peptides that inhibit the propagation of Newcastle disease virus. Arch Virol 2002. 147:981-993.

- 38 Schirrmacher V, Haas C, Bonifer R, Ahlert T, Gerhards R, Ertel C: Human tumor cell modification by virus infection: an efficient and safe way to produce cancer vaccine with pleiotropic immune stimulatory properties when using Newcastle disease virus. Gene Ther 1999;6:63-73.

39 Bank HL: Rapid assessment of islet viability with acridine orange and propidium iodide. In Vitro Cell Dev Biol 1987;24:266-273.

40 Samali A, Cai J, Zhivotovsky B, Jones DP, Orrenius S: Presence of a pre-apoptotic complex of pro-caspase 3, Hsp60 and Hsp10 in the mitochondrial fraction of Jurkat cells. EMBO J 1999; 18:2040-2048.

41 Hsu YT, Youle RJ: Nonionic detergents induce dimerization among members of the Bcl-2 family. J Biol Chem 1997;272:13829-13834.

42 Hsu YT, Youle RJ: Bax in murine thymus is a soluble monomeric protein which displays differential detergent-induced conformations. J Biol Chem 1998;273:10777-10783.
43 Willie AH: Glucocorticoid-induced thymocyte apoptosis is associated with endogenous endonuclease activation. Nature 1980;284: 555-556.

44 Everett H, McFadden G: Apoptosis: an innate immune response to virus infection. Trends Microbiol 1999;7:160-165.

-45 Manon S, Chaudhuri B, Guerin M: Release of cytochrome $c$ and decrease of cytochrome $c$ oxidase in Bax-expressing yeast cells, and prevention of these effects by coexpression of Bcl-X . FEBS Lett 1997;415:29-32.

46 Mikhailov V, Mikhailova M, Pulkrabek DJ, Dong Z, Venkatachalam MA, Saikumar P: $\mathrm{Bcl}-2$ prevents Bax oligomerization in the mitochondrial outer membrane. J Biol Chem 2001;276:18361-18374.

47 Ravindra PV, Tiwari AK, Ratta B, Chaturvedi U, Palia SK, Chauhan RS: Newcastle disease virus-induced cytopathic effect in infected cells is caused by apoptosis. Virus Res 2009;141:13-20.

48 Chipuk JE, Kuwana T, Bouchier-Hayes L, Droin NM, Newmeyer DD, Schuler M, Green DR: Direct activation of Bax by p53 mediates mitochondrial membrane permeabilization and apoptosis. Science 2004;303:1010-1014.

49 Yang E, Zha J, Jockel J, Boise LH, Thompson CB, Korsmeyer SJ: Bad, a heterodimeric partner for $\mathrm{Bcl}-\mathrm{X}_{\mathrm{L}}$ and $\mathrm{Bcl}-2$, displaces $\mathrm{Bax}$ and promotes cell death. Cell 1995;80:285291.

50 Desagher S, Osen-Sand A, Nichols A, Eskes R, Montessuit S, Lauper S, Maundrell K, Antonsson B, Martinou JC: Bid-induced conformational change of $\mathrm{Bax}$ is responsible for mitochondrial cytochrome $\mathrm{c}$ release during apoptosis. J Cell Biol 1999;144:891-901.

51 Strasser A: The role of BH3-only proteins in the immune system. Nat Rev Immunol 2005; 5:189-200.

52 Willis SN, Adams JM: Life in the balance: how BH3-only proteins induce apoptosis. Curr Opin Cell Biol 2005;17:617-625.

53 Martin-Latil S, Mousson L, Autret A, Colbere-Garapin F, Blondel B: Bax is activated during rotavirus-induced apoptosis through the mitochondrial pathway. J Virol 2007;81: 4457-4464.

54 Deng L, Adachi T, Kitayama K, Bungyoku Y, Kitazawa S, Ishido S, Shoji I, Hotta H: Hepatitis $\mathrm{C}$ virus infection induces apoptosis through a Bax-triggered, mitochondrionmediated, caspase 3-dependent pathway. J Virol 2008;82:10375-10385.

55 Su J, Wang G, Barrett JW, Irvine TS, Gao X, McFadden G: Myxoma virus M11L blocks apoptosis through inhibition of conformational activation of Bax at the mitochondria. J Virol 2006;80:1140-1151.

- 56 Taylor JM, Quilty D, Banadyga L, Barry M: The vaccinia virus protein F1L interacts with Bim and inhibits activation of the pro-apoptotic protein Bax. J Biol Chem 2006;281: 39728-39739. 